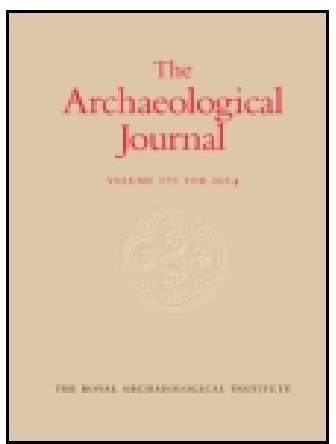

Archaeological Journal

\title{
On the Transition between the Palaeolithic and Neolithic Civilizations in Europe
}

\section{Robert Munro LL.D.}

To cite this article: Robert Munro LL.D. (1908) On the Transition between the Palaeolithic and Neolithic Civilizations in Europe, Archaeological Journal, 65:1, 205-244, DOI:

10.1080/00665983.1908.10853083

To link to this article: http://dx.doi.org/10.1080/00665983.1908.10853083

央 Published online: 17 Jul 2014.

Submit your article to this journal $₫$

Џ Article views: 2

Q View related articles $\asymp$

4 Citing articles: 1 View citing articles 지 


\section{ON THE TRANSITION BETWEEN THE PALAEOLITHIC AND NEOLITHIC CIVILIZATIONS IN EUROPE.:}

\section{By ROBERT MUNRO, LL.D.}

The story of mankind, as disclosed by their teleological inventions and the ingenuity displayed in adapting themselves to the vicissitudes of the changeable environment which obtained in Europe during the Quaternary period, forms a unique chapter in the history of the organic world. In exploiting the trail of their existence throughout the dim vista of bygone ages, as revealed by the waifs and strays which they have dropped by the way, there is one special characteristic applicable to all their productions which must be steadily kept in mind in dealing with such an inquiry, and that is, that every object bears the impress of the skill and intelligence of its manufacturer. On this assumption it follows that the tools, weapons, ornaments, and other relics of the prehistoric inhabitants of the world, form a graduated scale of the progressive culture and civilization of their owners. This is the magic key by which the long hidden secrets of past humanity are now being unlocked. Owing, however, to the inevitable disintegration, which sooner or later overtakes all organic compounds, only a few of their handicraft products have resisted the gnawing tooth of time to the present day. For this reason the most ancient human relics now extant consist of objects made of such durable material as flint and other hard stones, which are incidentally met with on the highways and haunts of their primeval owners, or intentionally disinterred from the dust-bins of ages.

The evidential materials, available in the discussion of the special problem which forms the heading of this article, are based on a combination of facts derived from stratigraphy, archaeology and palaeontology, which, being supplementary to each other, strengthen the final

1 Read before a Meeting of the Institute on June 6th, 1908. 
deduction in proportion to the amount of agreement between the respective results elicited from these different lines of research. But, unfortunately, the data which might have been forthcoming, through one or other of these departments, are often wanting, or too fragmentary to be of ethnical value-a condition of things which has sometimes led the most competent explorers to formulate conclusions on insufficient grounds. Apparently, this accounts for the diversity of opinion which has long permeated archaeological circles with regard to the relation between the Palaeolithic and Neolithic civilizations of Europe. Before proceeding to the discussion of the main question a few preliminary remarks are necessary, by way of defining the special characteristics of the two civilizations and so as to bring into relief the nature of the so-called hiatus which, according to some authorities, separates them.

The two chief sources of our knowledge of the earliest inhabitants of Europe are, (1) some ancient river gravels containing stone implements and bones of extinct animals reposing at various heights on the slopes of present, or former, river valleys, the waters of which now flow at considerably lower levels: and (2) a number of caves, rock-shelters and other inhabited sites, which have yielded to the explorer not only stone implements but other objects made of various materials, as well ds a heterogeneous mass of food-refuse, chiefly the broken bones of the wild animals on which their occupants feasted. Little is known ethnologically of the Driftmen, beyond the fact that they manufactured rude stone implements generally made of flint, and mostly of the type known in France as the coup de poing. This is supposed to have been the earliest type of hand implement invented, and, from its wide distribution in the Old World, must have been regarded by the then civilized world as the ne plus ultra of human craftsmanship. On the other hand, the relics of the Cave-men are so numerous, varied and suggestive, that the progressive march of their owners to a higher state of culture can be pictorially pourtrayed by the slow accretions which time and experience have made to the development of their mechanical tools. At the close of the Palaeolithic period 
in Central Europe they developed a remarkable taste for art, and cultivated its principles so effectually that they have bequeathed to us a veritable art gallery of over 400 pieces of sculpture and engraving, so true to their natural models that many of them compare favourably with analogous works of the present day. They also, in some instances, adorned the walls of the caverns they frequented with incised outlines of the neighbouring fauna and made colour drawings of them in black and ochre.

There is a consensus of opinion among archaeologists that the implements of the Drift gravels are older than those of the caves, one reason for this statement being that the former are ruder in point of execution than the latter ; also that the coup de poing, in the fow instances in which it has been found in caves, was invariably located in a stratum beneath the debris which contained characteristic relics of the Cave-men.

On this point Professor Boyd Dawkins writes as follows :

"In the course of this chapter we have seen that the River-drift implements in the caves of Cresswell Crags, of Kent's Hole, and of the Grotte de l'Eglise, are found in the strata below those with the implements of the Cave-men, and consequently that the River-drift men lived in Britain and France before the Cave-men. We have also noted that the latter are in a different stage of culture from that which was enjoyed by the former, the implements being not only better, but, taken as a group, of a different kind, although some simple forms, such as the flake, scraper, and hammer-stone, are common to both." (Early Man in Britain, p. 230.)

M. Gabriel de Mortillet adopted a method of classifying relics of the Palaeolithic period which is practically founded on the technical skill disclosed in their manufacture. The progressive stages of culture in the chronological sequence thus established he divided into five epochs, viz., Chelleen, Mousterien, Solutrien and Magdalenien, names derived from those of the most typical stations then known. According to this nomenclature the earliest troglodytic station was le Moustier, situated on the left bank of the Vezere (Dordogne). During its habitation by man the climate was cold and damp, and among the contemporary fauna were the mammoth, woolly rhinoceros, cave-bear, and musk-ox. 
The special features of the industrial remains of this period were the scarcity of the coup de poing, and the splitting up of flints into smaller tools, such as scrapers, trimmed flakes, etc. The next station in ascending order was the open-air encampment of Solutre (Saone-etLoire). The stage of civilization here disclosed was characterised by great perfection in the art of manufacturing flint implements, especially spear- and lanceheads in the form of a laurel leaf, and by the abundance of horses and reindeer which were used by the inhabitants as food. The climate was mild and dry, the great glaciers were on the wane, and the rhinoceros seems to have disappeared from the scene. The third and last of the typical stations was the well-known rock-shelter of La Madelaine (Dordogne), characterised by the abundance of objects made of bone and horn, the development of a remarkable artistic talent, the predominance of a northern climate and fauna, and the extinction of the mammoth towards the close of the period.

Concurrent with these evolutionary improvements in the social conditions and resources of the Palaeolithic people there were marked changes in the environmentphysical, geological, and climatal-which prove that there was a vast interval of time between the Riverdrift men and the later Cave-men of France. When Neolithic tribes first appeared in Europe the physical causes, which were slowly affecting the distribution of land and water, had already moulded the European continent to about the same limits as it now possesses, one marked change being that the British Isles were no longer part of it. This indicates a short chronological range for Neolithic civilization in comparison with that for the Palaeolithic, as suggested by the time that has rolled past since the high river gravels were deposited and the valleys excavated to their present levels. It is, however, the striking contrast between the ways, works, and methods of living of the two peoples which has been chiefly adduced as the principal argument in support of the theory that their respective civilizations had no evolutionary connection. But it does not follow from the disparity of the relics, however great, that the two races had not set eyes on each other. What better 
parallel could be instanced than the Red Indians and modern Americans, whose civilizations are so different that, if estimated by their respective implements, weapons, tools, and ornaments, they might be said to be separated by a long interval of time; and yet they have lived together for centuries. M. Gabriel de Mortillet, in bringing his system of classification (as above described) before the members of the International Congress of Anthropology and Prehistoric Archaeology in 1872 , thus expresses his views :

"Entre les diverses epoques paleolithiques, on suit le developpement régulier et logique de l'industrie; on en trouve des transitions et des passages. Des degres, des points intermediaires, peuvent encore faire defaut, mias on sent, on reconnaît, qu'il y a suite continue. Il n'en est plus de même entre le paleolithique et le néolithique, entre le Magdalenien et le Robenhausien. Il y a la une large et profonde lacune, un grand hiatus; il y a une transformation complete."

"Avec le Magdalenien disparaissent les animaux quaternaires, le Grand Ours, le Mammouth, le Megacere; avec le Magdalenien emigrent les especes des regions froides qui peuplaient nos plaines; le Renne, le Gluton, le Boeuf musque, remontent vers le pole; le Chamois, le Bouquetin, la Marmotte, gagnent le sommet neigeux de nos montagnes.

"Avec le Robenhausien (neolithique) ont apparu non seulement les instruments en pierre polie, mais encore la poterie, les monuments, dolmens et menhirs, les animaux domestiques et l'agriculture. C'est donc un changement complet." (Comple Rendu (1872), p. 440.)

The doctrine here advocated by De Mortillet was then held by a majority of the ablest palaeontologists of the day, at the head of whom stood Edward Lartet. Dr. Broca, however, and a few others, maintained that the flint tools of the later Palaeolithic stations and those of Neolithic times were not so dissimilar as to justify the idea that there was any break in the continuity of this industry in Europe; and further, that there was valid evidence to show that the extremely dolichocephalic race of the sepulchral caverns of the Lozere (Baumes Chaudes, l'Homme Mort, etc.), so well explored by Dr. Prunieres, were the descendants of the Cave-men.

At the meeting of the same Congress held at Stockholm (1874), M. Cazalis de Foudouce reviewed the hiatus problem, in all its aspects, in a masterly paper entitled "Sur la Lacune qui aurait existé entre L'âge de la pierre taillee et celui de la pierre polie," in which he 
combated De Mortillet's theory on every point. His general conclusions were that the transition from the one civilization to the other was slow, but without interruption since the commencement of the Palaeolithic period down to the present day; that towards the close of that long period two or more different races had combined and ultimately developed the primary elements of Neolithic civilization; that the ameliorated climate attracted from time to time new immigrants who imported improved elements into the arts and industries; and finally, that the incoming tribes gradually absorbed the indigenous people of the old Stone Age, thus accounting for the persistence of the marked ethnic peculiarities of the Palaeolithic race in the populations of Europe of the present day.

Before considering subsequent and more recent investigations, bearing on the solution of this problem, it may be interesting to note the opinions held on the subject by one or two British anthropologists.

Writing in 1872, Sir John Evans thus expresses himself :- " There appears, in this country at all events, to be a complete gap between the River-drift and Surface Stone Periods, so far as any intermediate forms of implements are concerned; and here at least the race of men who fabricated the latest of the Palaeolithic implements may have, and in all probability had, disappeared at an epoch remote from that when the country was again occupied by those who not only chipped out, but polished their flint tools, and who were, moreover, associated with a mammalian fauna far nearer resembling that of the present day than that of Quaternary times." (Ancient Stone Implements, etc., p. 618.)

Professor Huxley, in discussing the problem in his essay on the Aryan question (1890), was unable to take a side in the controversy, though the continuity of the races seemed to him the more likely to be right.

"As I have already mentioned," he writes, "there is not the least doubt that man existed in north-western Europe during the Pleistocene or Quaternary epoch. It is not only certain that men were contemporaries of the mammoth, the hairy rhinoceros, the reindeer, the cave bear, and other great carnivora, in England and in France, but a great deal has been ascertained about the modes of life of our predecessors. They were savage hunters, who took advantage of such natural shelters as overhanging rocks and caves, and perhaps built themselves rough wigwams ; but who had no domestic animals, and have left no sign that they cultivated plants. In many localities there is evidence that a very considerable interval - the so-called hiatus-intervened between the time when the Quaternary or Palaeolithic men occupied particular 
caves and river basins, and the accumulation of the debris left by their Neolithic successors. And, in spite of all the warnings against negative evidence afforded by the history of geology, some have very positively asserted that this means a complete break between the Quaternary and the recent populations-that the Quaternary population followed the retreating ice northwards and left behind them a desert which remained unpeopled for ages. Other high authorities, on the contrary, have maintained that the races of men who now inhabit Europe may all be traced back to the Great Ice Age. When a conflict of opinion of this kind obtains among reasonable and instructed men, it is generally a safe conclusion that the evidence for neither view is worth much. Certainly that is the result of my own cogitations with regard to both the hiatus doctrine (in its extreme form), and its opposite-though I think the latter by much the more likely to turn out right. But I hesitate to adopt it on the evidence which has been obtained up to this time." (Collected Essays, vol. vii, p. 318.)

Mr. J. Allen Brown contributed to the Anthropological Institute (1892) an elaborate paper "On the continuity of the Palaeolithic and Neolithic periods," in which his line of argument is thus stated :

"The supposed break in the continuity of the Stone Age in this country is bridged over by the discovery of implements of later Palaeolithic type and of others which from their form may be regarded as of transition or intermediate age, in some combes and dry valleys associated with deposits of chalk and flint rubble in parts of Sussex, as well as with other accumulations and formations to which I shall refer as being of more recent date than the high level river drifts. The gradual change in mammalian life which appears to have accompanied these higher stages of the Stone Age will also be considered." (Journal, vol. xxii, p. 67.)

A primâ facie objection to Mr. Brown's method is that no legitimate inference can be drawn from a graduated series of stone implements picked up on the surface, as in all large finds and workshops of Neolithic implements a sufficient number of unfinished, or roughly made, specimens may be readily found which, in appearance, can be paralleled with the later Palaeolithic types.

In the following year (1893), and at the same Society, Professor Boyd Dawkins read a paper "On the relation of the Palaeolithic to the Neolithic period" in which his opinion is thus stated :

"If, however, the results as I read them, over the whole of Europe, point to the great interval dividing the Palaeolithic from the Neolithic Age, and to the great geographical break between them, still more shall we find these conclusions confirmed by the contrast between the Palaeolithic and Neolithic civilizations. On the one hand-it is 
unnecessary to labour the minute details-the Palaeolithic man lived by hunting the wild animals on the Pleistocene continent, armed with rude implements of stone and bone, and ignorant of all the domestic animals, including the hunting dog. He was a fire-using nomad, without fixed habitation. On the other hand, the Neolithic man appears before us a herdsman and tiller of the ground, depending on his domestic animals, and the cultivated fruits and seeds rather than on hunting; master of the potter's art, and of the mysteries of spinning, and weaving, and seeking the materials for his tools by mining. He lived in fixed habitations, and buried his dead in tombs. There is obviously a great gulf fixed between the rude hunter civilization of the one, and the agricultural and pastoral civilization of the other, a gulf which has not yet been bridged over by discoveries in any part of the world," (Journal, vol. xxiii, p. 248.)

In the evening address, "On man as artist and sportsman in the Palaeolithic period," which I had the honour of delivering at the Southport Meeting of the British Association (1903), I thus alluded to the hiatus theory :

"When the physical conditions which called into being the accomplishments and special attainments of Palaeolithic man had passed away, and the peculiar fauna of the glacial period disappeared from the lowlands of Central Europe-some by extinction, and others by emigration to more northern regions or to the elevated mountains in the neighbourhood-we find the inhabitants of these old hunting grounds in possession of new and altogether different sources of food. Finding the former supplies becoming so limited and precarious that it was no longer possible to live a roaming life, now gathering fruits and seeds, and now hunting wild animals, they fell somehow into the way of cultivating special plants and cereals, and rearing certain animals in a state of domestication. Whether this new departure was a product of the intelligence of the descendants of the Palaeolithic people of Europe, or derived from new immigrants into the country, is a debatable question. At any rate the expedient was eminently successful. It was in reality the starting point of Neolithic civilization, and henceforth there was a rapid increase in the population. They cultivated a variety of fruits, wheat, barley and other cereals; they reared oxen, sheep, goats, pigs, horses and dogs; they became skilled in the ceramic art, and in the manufacture of cloth by spinning and weaving wool and fibrous textures; they ground stone implements so as to give them a sharp cutting edge; in hunting the forest fauna of the period they used, in addition to spears, lances and daggers, the bow and arrow ; they built houses, both for the living and the dead-thus showing that religiosity had become an active and governing principle among them. But of the artistic taste and skill of their predecessors they had scarcely a vestige, and whatever they did by the way of ornament consisted mainly of a few scratches, arranged in some simple geometrical pattern. The fundamental principles of the two civilizations are really so divergent that the Neolithic can hardly be regarded as a local development of the latest phase of that of the Palaeolithic period in 
Europe. The probability is that, while the isolated colonies of reindeer hunters were still in existence, people, possibly of the same stock, were elsewhere passing through the evolutionary stages which connected the two civilizations together." (Proc. R. S. Edinburgh, vol. xxv, p. 123.)

It appears to me that the difficulty about this socalled hiatus arises partly from a misconception of the facts. Although the progress of the Palaeolithic people to a higher civilization had been extremely slow, still their handicraft products, at successive stages, indicate not only an advance in mechanical skill and execution of design, but a deeper insight into the phenomena of nature. Hence the magnitude of the differences observed between different groups of Palaeolithic remains, when contrasted with the products of Neolithic culture, must largely depend on the degree of civilization to which the owners of the former had attained. It is not an uncommon occurrence to come upon a cave containing Neolithic and Palaeolithic remains separated from each other only by a thick stratum of stalagmite, as for example in Kent's Cavern, in which case there can be no doubt that the facts prove a hiatus, representing a period of time which can only be estimated by great physical changes in the environment and the extinction of some of the local fauna. But, let us suppose a case where the two culture beds are not separated by stalagmite, and that we have satisfactory evidence that the owners were contemporary with each other, how would this condition of things affect the hiatus theory? In this case the hiatus would remain precisely as before, only the element of time would be reduced to the vanishing point. The difference of technical skill disclosed by these respective remains constitutes in many instances the only barrier which has not been bridged over. Indeed, it is the occasional absence of a transition stage between the two civilizations which forms the strongest argument in support of the current opinion that the Neolithic races were immigrants into Western Europe. I am not, however, aware of any evidence which actually negatives the idea that the Quaternary men of Europe survived till the arrival of the Neolithic tribes. If the former were absorbed peacefully by the latter the amalgamated population would necessarily adopt the mode of living 
best adapted to the altered conditions of the environment, i.e., Neolithic methods. The gradual disappearance of the reindeer and other mammalia would henceforth necessitate a complete change in their manner of living. The nomad hunter would soon sink into the herdsman, and the mechanic would readily lay aside his roughly chipped tools for those with finely ground and polished edges. On the other hand, should a few caves and rock-shelters in one or two favourite localities continue to be inhabited after the arrival of the Neolithic tribes on the scene there might be few traces of amalgamation to be found. Such points of contact have, however, been discovered in more recent times in various parts of the European Continent. It is on the validity of the evidence furnished by these transition stations that the hiatus problem must be finally solved. Stations with undisturbed stratified debris of the two civilizations are now so numerous that only a few of the more important can be here considered.

\section{(1) Mas-d'Azil.}

The late M. Ed. Piette was one of the most strenuous advocates of the existence of a transition period, evidence of which he had obtained in several caves and rock-shelters situated in the south-west of France among the rocky regions to the north of the Pyrenees, the most important of which is the Cavern of Masd'Azil (Ariege). A résumé of his researches on this site was brought before the 10th Congress of Anthropology and Prehistoric Archaeology held in Paris (1889), with the result that there was a consensus of opinion among the members that his discoveries proved that the interval between the two civilizations in that locality had been of short duration. Some of the more remarkable relics were exhibited at the meeting, where I had an opportunity of inspecting them. Subsequently (1895) M. Piette published a more detailed account of the structure and contents of the stratigraphical deposits at Mas-d'Azil (L'Anthropologie, vols. vi and rii), of which I subjoin a brief outline.

Above a stratum containing relics characteristic of the 
Reindeer age, but beneath deposits with relics equally characteristic of the Neolithic period, he describes two beds the combined depth of which amounted to about

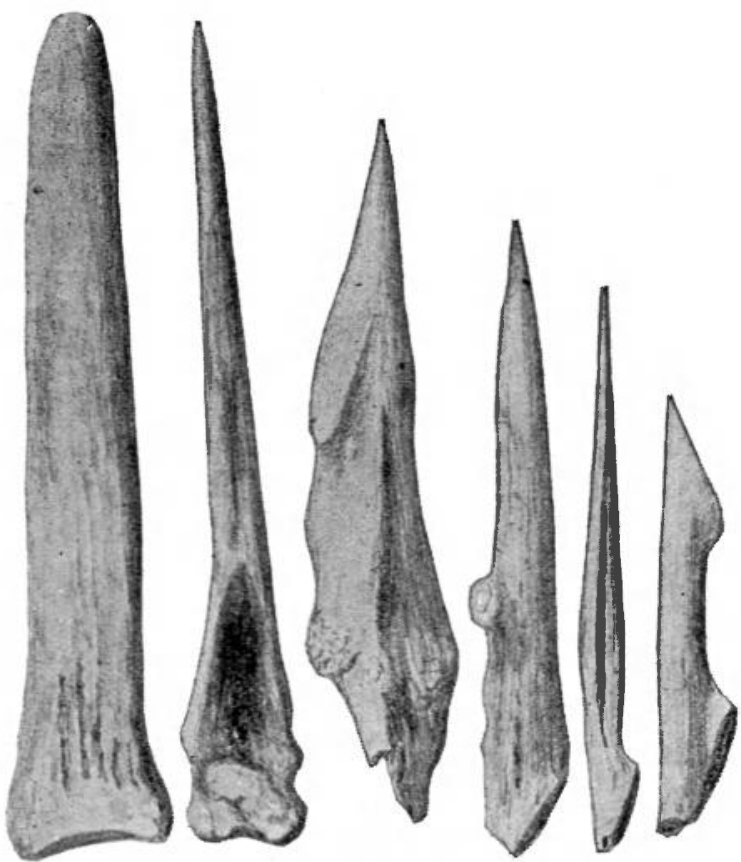

FIGS, 1-6.

Bone implements from the Cave of Mas-d'Azil, France. (Col. Piette.)
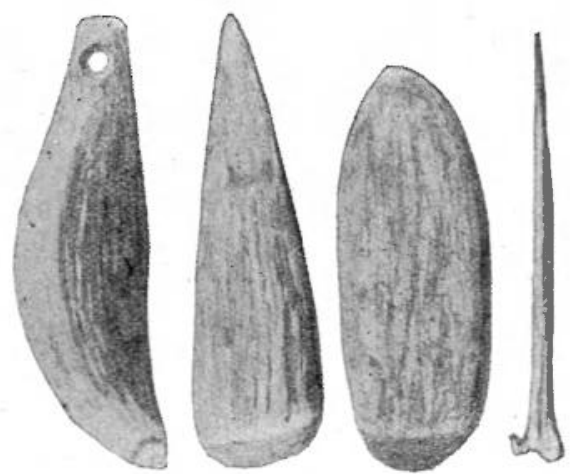

FIGS, 7-10.

$\Delta$ bear's tooth, a horn chisel, a stone implement, and a bone pin from

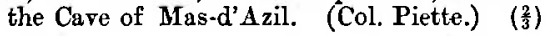


4 feet, which yielded the relics supposed to indicate a transition period.

The lower of these two beds was composed chiefly of ashes and wood-charcoal, intermingled with some fallen rocks. The thickness of this bed was $25 \frac{1}{2}$ inches, and among its contents the following worked objects were found : flint knives and scrapers, a number of perforated deer-teeth arranged as if they had formed a necklet, also perforated teeth of various other animals (fig. 7) ; pins, polished pointers and spatulae of bone (figs. 1 to 6); barbed harpoons made of stag-horn, some being perforated at the butt-end with an oval or round hole, and others having the barbs on one side only (figs. 11 to 14); also a large number of pebbles of quartz or schist-such as could be picked from the bed of the river-some round-nosed and pestle-shaped, showing usage markings at one end (fig. 9), and others flat and oblong having various devices painted on them with peroxide of iron (fig. 15). The fauna was represented by bones of the stag, Cervus canadensis, roe-buck, chamois, ox, horse, common bear, wild-boar, badger, wolf, beaver, rat, and some birds and

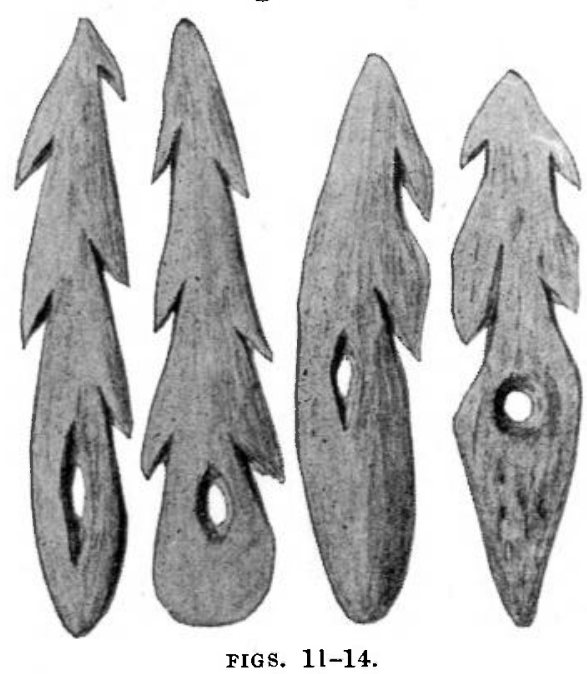

Harpoons made of stag-horn from the Cave of Mas-d'Azil. (Col. Piette.) fishes. Grains of wheat and a variety of fruit stones and seeds were also identified. The larger bones of two human skeletons, which appeared to have been buried after the flesh had been removed, had also been marked with red patches of the peroxide of iron.

Superimposed this bed, but passing from it almost insensibly, were deposits of

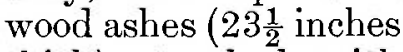
thick) streaked with $\left(\frac{2}{3}\right)$

bands of grey, white, and red, in which were imbedded quantities of land shells (Helix nemoralis), evidently the remains of repasts. These shell heaps were inter- 
calated between the layers of ashes, and extended over several yards with a maximum depth of about 1 foot. In this bed (Assise a escargots) were also found harpoons and other relics similar to those in the bed of coloured pebbles; and in addition to these there were portions of small chisel-like implements of stone with sloping and abraded ends (fig. 16), but no regular stone axes-only in the superincumbent layers were the latter found; and above all were deposits containing objects of bronze and iron. It was also observed that the snail shells had become altered to the rariety known as Helix hortensis, which, it is said, indicated a drier climate.

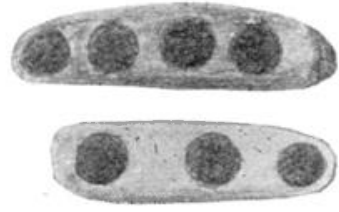

FIG. 15 .

Pebbles painted with red spots from the Care of Mas-d'Azil. (Col. Piette.) (g)

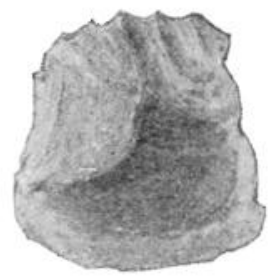

FIG. 16 .

Flint implement with a polished cutting edge from the Cave of Mas-d'Azil.

(Col. Piette.) (3)

According to M. Piette there were changes in the external environments which could be correlated with these successive deposits. As the Reindeer period passed away the climate became ameliorated but humid, as inferred from the presence of fruit trees and the cultivation of grain. The people appear to have lost their artistic taste for carving on bones, and instead of it they manufactured harpoons of red-deer horn without a trace of ornament, painted selected pebbles with quaint devices or mere lines and round spots (fig. 15), and practised some obscure sepulchral rites, in which the red paint on the desiccated bones seemed to play a part. M. Piette classified these painted stones into numerals, symbols, pictographs, and alphabetical characters, and to illustrate his views he issued a series of coloured plates showing the designs on some hundreds of these pebbles. Can there be any doubt about the genuineness of these pebbles?

The chief interest in the discoveries at Mas-d'Azil lies 
in the harpoons of red-deer horn, the real significance of which had then, for the first time, been recognised, although a few specimens had already been found in one or two other caves and rock-shelters of the district. Since then, however, they have been discovered in considerable numbers, and are regarded as typical relics of the transition period. In face of these, and other rapidly accumulating facts, proving the existence of deposits of human debris containing relics stratigraphically proved to be later than those of the Reindeer period, but older than those of the polished Stone age, De Mortillet abandoned the hiatus theory and filled up the gap by adding a new epoch to his previous classification of the Palaeolithic age, which he called Tourassien, after the Grotte de la Tourasse (Haute-Garonne). This station was explored in 1891 by MM. Chamaison and Darbas, and yielded, along with a few other bone relics of intermediary forms, no less than a dozen harpoons of the kind now under review. The deposits in which they were found lay beneath a series of Neolithic burials. The flatness, which is characteristic of these harpoons, is due to the fact that the texture of red-deer horn is spongy in the interior, and consequently it is only the outside of the horn that is used in their manufacture. On the other hand, the harpoons of the Palaeolithic period have round stems and conical butts, with two projecting knobs close to the butt-end, instead of a hole, for keeping the string from falling away when the harpoon becomes eliminated from the handle. Altogether, they have a finer finish than the former, and show, either two rows of barbs, one on each side, or one row, having the barbs more closely set. The larger specimens are invariably made of reindeer horn, but the smaller ones are sometimes made of bone. They are widely distributed on all the Magdalenien stations on the Continent. A specimen has been found in Kent's Cavern.

\section{(2) La Grotte de Reilhac.}

Another station which has yielded flat harpoons is the Grotte de Reilhac (Lot), described by MM. Cartailhac and Boule (1889). Although the circumstances in which 
the Reilhac specimens have been found are not so definite as to give them a precise chronological value, the facts are by no means inconsistent with the opinion that they belonged to the same age as those from Mas-d'Azil. The contents of the cave having been largely removed by the proprietor before the matter came under the notice of the explorers, there remained only a small portion of undisturbed material from which the relative sequence of the deposits could be ascertained. So far as the contents of the deposits were determined, they were as follows, from above downwards :

(a) A bed of blackish earth containing clay, charcoal, angular pieces of the limestone rock, and shells (Helix nemoralis), mostly very much broken. The soil, generally loose, was here and there cemented by stalagmitic deposits. Bones of the red-deer, ox, and horse, together with small worked flints and minute fragments of pottery, were also collected in it.

(b) Then came a veritable breccia of rabbit bones, mixed with charcoal, ashes, and angular pieces of rock, the whole cemented by a stalagmitic matrix. It also contained, especially in its lower portion, the bones of larger animals, and one of the explorers found in it a portion of a slender bone ornamented by cut notches like a tally stick.

(c) The next stratum was of great thickness (over 6 feet), and presented a reddish colour which it had gradually assumed. Its substance was a homogeneous clayey earth mixed with the usual angular fragments from the walls of the cave, in which were found many flint implements and worked bones, some of the latter being characteristic of the Reindeer period.

In classifying these three deposits according to the remains of the fauna collected in them, the authors state that the superficial layer $(a)$ represented the Neolithic period, and that both $(b)$ and $(c)$ corresponded with the Reindeer age. After contrasting the scarcity of the remains of the reindeer with the abundance of those of 
the red-deer, and commenting on the almost entire absence of the extinct and emigrated animals, they make the following remarks pertinent to the problem at issue :

"Cette absence totale d'animaux éteints et d'animaux localises aujourd'hui dans les regions septentrionales, jointe d̀ la rarete relative des ossements de Rennes, nous porte a penser que les depôts a ossements de la grotte de Reilhac correspondent a la fin du Quaternaire superior, et peuvent etre regardes comme se rattachant de très pres a l'epoque actuelle." (La Grotte de Reilhac, 1889, p. 27.)

Considering the comparative lateness of the archaeological horizon here indicated, and the impossibility of assigning the worked bone and horn objects to their
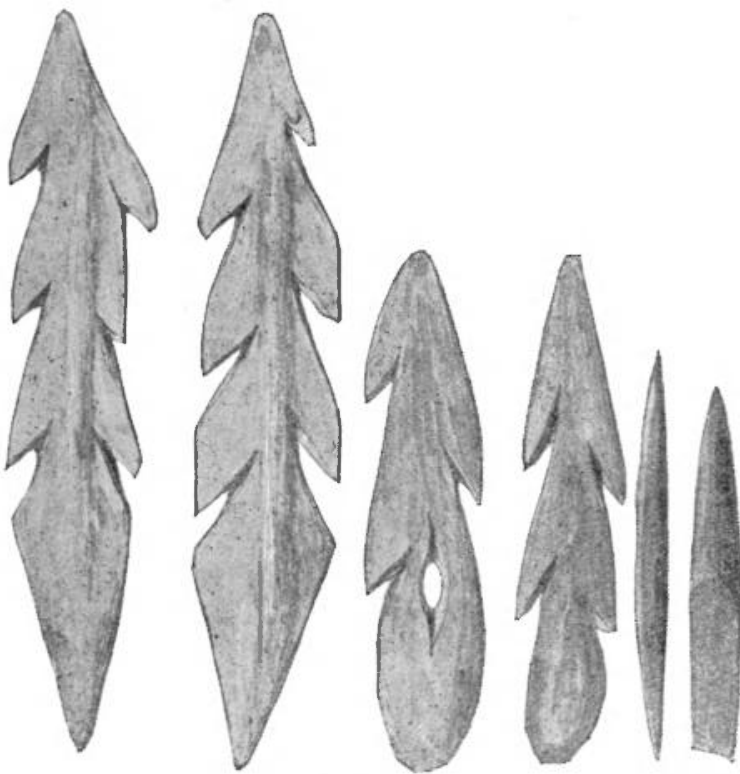

FIGS. 17-22.

Four harpoons and two small implements mnde of the horns of Cervidae from the Grotte de Reilhac. ( $\left.\frac{(2)}{3}\right)$

precise position in the deposits-most of them having: been discovered and dispersed among collectors before the authors came on the scene-it is peculiarly significant to find among them harpoons (figs. 17 to 20) so precisely similar to those from Mas-d'Azil. Their association with other harpoons characteristic of the Reindeer period is not, therefore, fatal to the theory that the former were 
products of the Neolithic period. Indeed the same uncertainty hangs over most of the specimens of this type of harpoon found on Reindeer stations, partly due to the fact that their characteristic differences had not then attracted attention, and consequently they had not been recognised as belonging to a different civilization.

Another point of uncertainty about these harpoons is whether or not the flat specimens were exclusively made of red-deer horn. The butt-end of one, with an oval perforation, and described as made of reindeer horn, was found in La Madeleine (Reliq. Aruitanicae, p. 160, fig. 57) ; another, described as flat, with a round hole at the butt, and made of reindeer horn, is recorded from the Grotte de Vache and figured in Musee Prehistorique (fig. 187); and a third, flat and perforated (the material not stated), was found in Laugerie Basse (Proc. R.S. Edinburgh, vol. xxv, Pl. III, fig. 9). If, therefore, it be true that some of these flat harpoons were made of reindeer horn it only adds to the importance of this link between the two civilizations, as it proves that when the scarcity of the reindeer material was increasing the old Palaeolithic people gradually resorted to the horn of the red-deer as a substitute for making their harpoons, though inferior in quality to the former, and that they had already altered the form to suit the nature of the new material.

The flint implements found in the Reilhac settlement include types common to all the Palaeolithic epochs, as well as others which are considered to belong to the Neolithic age. Among the relics characteristic of the latter are polished stone axes, and the deer-horn sockets with which they were fastened into the wooden handle, grain bruisers, and fragments of pottery. Curiously enough .a number of perforated phalangeal bones of the horse and ox, formerly supposed by Lartet and others to be whistles, are also noted. The station would thus appear to have been occupied with little interruption from Palaeolithic to Neolithic times.

\section{(3) The MacArthur Cave.}

The MacArthur Cave was discovered in 1894 by quarrymen while removing stones for building purposes from a 
cliff facing the bay of Oban, and long regarded by geologists as marking the line of an old sea-beach. It was explored under the auspices of the Society of Antiquaries of Scotland, and a report of the result was read by Dr. Joseph Anderson at a meeting of the Society on 11th March, 1895 (Proc., vol. xxix).

The contents of the cave consisted (1) of a superficial layer of black earth, in which human remains were found, including two skulls, showing that its final purpose was a burial place; and (2) a food refuse heap composed of shells and the remains of animals, partly superimposed on, and partly intercalated with, sea gravel. This interesting debris is thus described by Dr. Anderson :

"It was found that underneath the layer of black earth there was a bed of shells, varying from 27 inches to about 3 feet in thickness, extending over the whole floor of the cave, and showing little or no intermixture of black earth or gravel, but here and there patches of ashes mixed with wood charcoal, and charred splinters of bone. Under this shell-bed was a bed of fine, clean gravel, composed entirely of small water-rolled stones. In this gravel, at the depth of about 18 inches (where the section was first made), there was intercalated a deposit of shells, which we at first spoke of as the lower shell-bed, but which proved to be of partial extent and unequal thickness, thinning out towards the sides and towards the mouth of the cave, and in several places presenting an irregular or patchy appearance in the section, as if the shells had been deposited in heaps or pockets in the gravel. Underneath this intercalated layer of shells the gravel extended for about 4 feet, or more, to the cave bottom, where it was mixed with large and small fragments of loose rock."

Both upper and lower shell-beds were composed of the shells of edible species, found on the neighbouring shores. and of the bones of land and marine animals, the entire mass being a true refuse-heap, evidently the result of a lengthened occupation of the cave by people who fed on the fauna represented in it. The bones were for the most part broken into splinters, both for the purpose of extracting the marrow and of manufacturing bone implements, of which a large number was collected. The same shells and bones of the same species of animals, as well as 
the varieties of bone implements, were found in both the upper and lower shell-beds.

All the implements recovered from the cave were made of bone or deer-horn, with the exception of three hammer stones, and twenty flints (three being natural nodules), mostly flakes and chips, " a few of which show secondary working, though none are really implements in the same sense of being fashioned and finished."

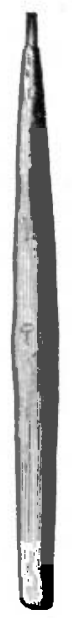

FIG. 23.

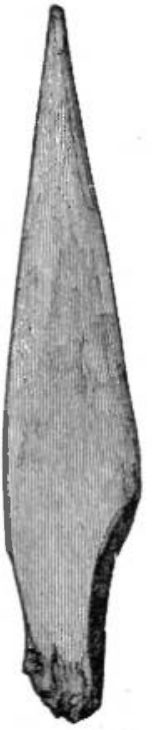

FIG. 24.

Bone pin. (Oban Care) Bone implement. (Oban $\left(\frac{1}{1}\right)$

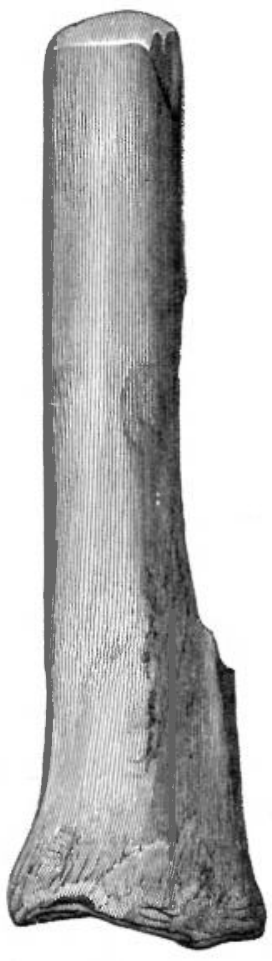

FIG. 25.

Implement made of leg. bone of a deer. (Oban.)

( $\left.\frac{3}{4}\right)$

The bone and horn implements consist of three pins (fig. 23), three borers (fig. 24), together with a few bone implements of a nondescript character, being merely pointed or flattened at the end ; one hundred and forty " round-nosed," chisel-ended implements, having an extraordinary likeness to each other (figs. 25 to 28); and seven harpoons (two being entire) made of deer-horn. The 
larger of the entire harpoons (fig. 30) is 6 inches long, has 4 barbs on each side and an oval perforation at the buttend. The other (fig. 29) differs from it only in being smaller ( $4 \frac{1}{4}$ inches in length) and having no perforation.

A mere glance at the illustrations of these bone implements, especially the harpoons, shows their striking similarity to those already described from Mas-d'Azil. No archaeologist can fail to be astonished at so remarkable a coincidence as that a group of human relics, from such widely separated localities as Oban and
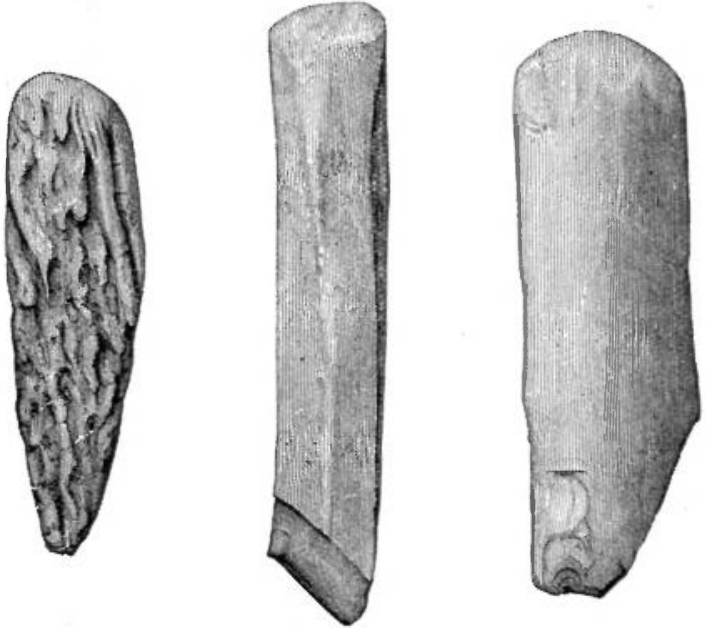

FIGs. 26-28.

Implements of bone and deer-horn from the Oban Cave. ( $\left(\frac{1}{1}\right)$

Mas-d'Azil, should be so similar. The harpoons agree, not only in the material of which they are made, viz., deer-horn, but also in the shape of the stem, the method of cutting the barbs, and the occasional presence of an aperture in the butt-end. We have seen that M. Piette assigned the Mas-d'Azil harpoons to an intermediate period between the Palaeolithic and Neolithic ages. Is the chronological horizon of the Oban troglodytes the same as the transition period of Mas-d'Azil ? We are not without some suggestive data on this problem, as we shall now endeavour to show.

There is no probable natural phenomenon which more satisfactorily accounts for the intercalation of such a mass of clean sea-gravel between the two shell-beds in the Oban 
Cave as that, during a storm, subsequent to the time when the cave had become a place of resort to man, the waves were forced into the cave, carrying with them a certain amount of shingle, which, after the abatement of the storm, had become the habitable floor of the cave, and over which the cave-dwellers again took up their quarters.

If this deduction be correct the importance of the Oban discovery cannot be over-rated, as it proves that man was an inhabitant of the district when the opening to the cave was on the sea-beach, and sufficiently near the water to permit the waves to enter it during a storm. The beach of today is, however, 100 yards distant, and the lower shell-bed lay fully 30 feet above present high-water mark; so that a change in the relative level of sea and land, to the extent of some 25 or 30 feet, must have taken place in that part of Scotland, since the troglodyte hunters of Oban feasted on the marine and land fauna of the district. But this is not the only evidence to prove that Scotland was inhabited by a race of people who manufactured implements of red-deer horn, and lived on shellfish and such marine animals as chance or strategy brought within their reach, before the last land elevation took place. Implements of deer-horn, associated with the

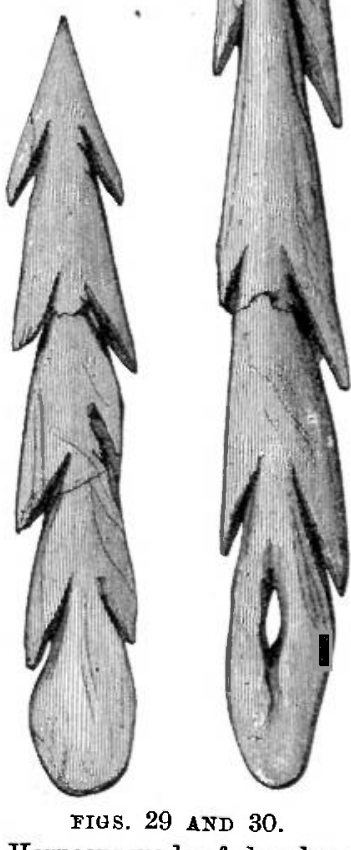

Harpoons made of deer-horn from Oban Cave. ( $\left.\frac{3}{4}\right)$ skeletons of whales, have been found in various parts of the valley of the Forth-localities which at the present time are the most highly cultivated in Scotland. The following is a brief report of these remarkable discoveries : 


\section{(4) Early Man in the Forth Valley.}

On the 17th September, 1889, Sir William Turner read a paper at the British Association, then held at Newcastle-on-Tyne, "On implements of stag's horn associated with whales' skeletons found in the Carse of Stirling." In this paper the author describes a perforated horn implement shaped like a hammer-axe head, 11 inches long, and 6 $\frac{1}{3}$ inches in its greatest girth (fig. 31). It is truncated at one end and bevelled into a cutting edge at the other, the perforation being not in the middle, but about 2 inches nearer the truncated extremity than the cutting edge. When found there was still a portion of a wooden handle in the hole. It was discovered in 1877, resting on the skull of the skeleton of a Balaenoptera, exposed in the course of drainage operations on the estate of Meiklewood, a few miles west of Stirling.

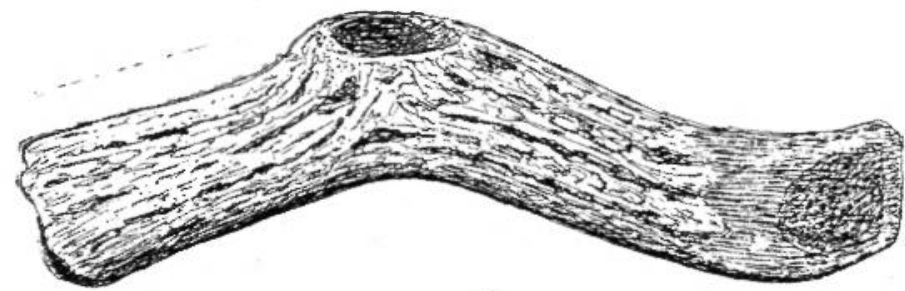

FIG. 31.

Hammer-axe head of stag's-horn, found with a whale's skeleton at Meiklewood, near Stirling. ( $\left.\frac{1}{3}\right)$

It is recorded that in 1819 , and in 1824 , implements of deer-horn, two of which had been perforated with a round hole, as if for a handle, had been discovered, along with the skeletons of whales, but they appear to have been lost. Sir William sums up his interesting report on these discoveries as follows :

"The discovery of those implements proves that, when the fertile land now forming the Carse of Stirling was submerged below the sea level, the surrounding highlands were inhabited by a hardy Caledonian race, who manufactured from the antlers of the red-deer useful tools and weapons. I have already stated that there is nothing in the form of these implements to lead one to suppose that they could be used in the chase of the whale as lances or harpoons. It is probable that the whales, by the side of which they were found, had been stranded during the ebb of the tide, and that the people had descended from the adjacent heights, and, with the aid of their chisels of horn, had spoiled the carcass of its load of flesh and blubber. In support of this view, 
I may state that the three skeletons along with which the implements were found were lying in proximity to the edge of the Carse-land, where it approached the adjacent high ground."'

As further evidence that prehistoric man wandered about the shores of these old inland seas, several shellheaps have been observed along the bluff of the old shore-line on both sides of the Avon, just where it enters the Carse, a locality which is still called Inveravon, although the present mouth of the river is several miles distant. The following extract from Memoirs of the Geological Survey (sheet 31) gives a description of one of these shell deposits:

"A section," writes Dr. Peach, F.R.S., " across a heap, 50 yards long by 20 wide was exposed in a road cutting, and showed many successive layers of shells-principally oysters - to a depth of three feet without the bottom being visible. The remains of fire-places were plentiful among the shells. Oysters seemed to have been preferred by the makers of the midden, though they had also used Anomia, the big 'horse mussel' (Modiola), the common mussel (Mytilus edulis), the whelk (Buccinum undatum), and periwinkle (Littorina littorea). Fragments of the large edible crab (Cancer pagurus) were also present. All the valves of the oysters were separate, except such as had been empty, and which still had barnacles and zoophytes in their interior. The mussel and other shells were found in separate nests, and not indiscriminately throughout the mound. Layers of sand were also found among the shells. All the middens observed occur on the bluff itself, or just at its base, as if, when it was the limit of high water, the people who formed the middens, after searching the shores during low water, had retreated thither to enjoy their feast while the tide covered their hunting ground. Few or no oysters are now found in the Forth above Borrowstounness."

\section{(5) The Rock-shelter of Druimvargie.}

In 1898, another discovery was made at Oban which yielded remains of human industry associated with a shell-heap and broken bones, precisely similar to those from the MacArthur Cave. This was a shelter situated at the base of a steep rock, called Druimvargie, and overlooking a marsh in which, some years ago, the remains of what were supposed to be a lake-dwelling

1 To those who wish to know further details of the discovery of these Carse whales, I recommend an article on the subject by Mr. David B. Morris, in which he gives the records of teu other whale remains. The article was pub. lished in the Proceedings of the Strrling Natural History and Archaeological Society for 1892 . See also Prehistoric Scotland. 
were found. As the lowest portion of this marsh is only a few feet above high water mark it would have been an inland bay when the sea stood so high as to wash the entrance to the MacArthur Cave, so that the two stations would then have been on opposite sides of a. small bay and, probably, be frequented by the same body of hunters. The floor of the shelter stood 34 feet above datum line, and its area measured some 10 feet square. The debris of human habitation and food refuse which became exposed on its floor had been covered over for ages by a deep talus. It was while clearing away this talus, preparatory to laying the foundations of a house, that the shell-heap and its relics were discovered. Among the relics were a few stone implements of waterworn pebbles, of an elongated shape and slantingly
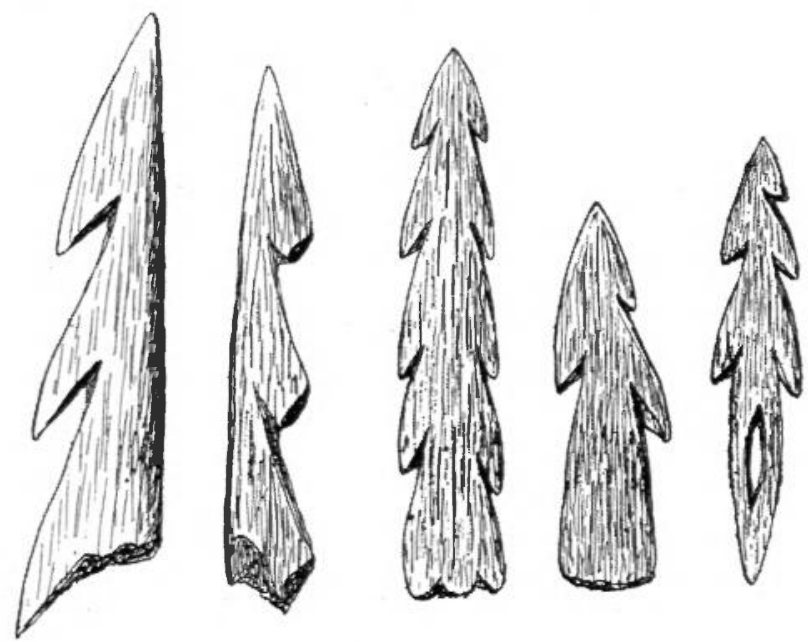

FIGS. 32-36.

Harpoons from Druimrargie, Caisteal-nan-Gillean, and̉ Newcastle-upon-Tyne.

abraded at one end, two or three bone borers, a portion of a deer-horn broken across a circular perforation, a number of "round-nosed," chisel-ended implements of bone, and the front portions of two harpoons, also of bone, but of the same type as the horn harpoons from the MacArthur Cave-differing from them only in having the barbs on one side (figs. 32 and 33). M. Piette also records unilateral-barbed harpoons from the Cave of Mas-d'Azil, and they are fairly common on the later 
Palaeolithic stations, though made of reindeer horn. Hence the discovery of this variety at Oban only strengthens the remarkable analogy between these French and Scottish harpoons.

\section{(6) Shell-ILeaps in Oronsay.}

Caisteal-nan-Gillean.-Bone harpoons and implements of bone and stone, similar to those from the MacArthur Cave and the Rock-shelter of Druimvargie, have been found in a shell mound known as Caisteal-nan-Gillean, in the island of Oronsay, explored by Mr. Symington Grieve and Mr. William Galloway. The results have been described by Mr. Grieve in his work on The Great Auk, or Garefowl; and by Dr. Joseph Anderson in the Proceedings of the Society of Antiquaries of Scotland (vol. xxxii), after Mr. Galloway's collection had been acquired for the National Museum. Caisteal-nanGillean is (or was) an isolated mound between a range of sand-dunes and the sea, measuring about 150 feet in diameter, and an average height of 25 feet. Its surface was covered with grassy turf, having blown sand underneath to a depth of from 1 to 5 feet. "Below this covering," writes Dr. Anderson, "an accumulation of shells and bones, in a series of layers, mingled with sand and ashes, extended downwards for a total depth of about 8 feet. Underneath this refuse-heap the substance of the mound consisted of blown sand in layers, the upper part of each line defined by a thin line of dark mould, with a few sea and land shells intermixed, but no implements or other remains of human occupancy."

The bone and horn implements found in this shell-heap consisted of eleven harpoon-heads (figs. 34 and 35), three bone awls, and no less than one hundred and fifty of the round-nosed, chisel-like implements, similar to those from the caves of Oban. The stone implements, numbering over two hundred, were elongated water-worn pebbles, worked at one end into the "round-nosed ending," so characteristic of both the stone and bone chisels. They are supposed to have been utilized by the people who formed this shell-heap as "limpet hammers." Besides the above named objects there were eight fragments of 
perforated implements of deer-horn, and others roughly cut round the circumference and then broken across; two small anvil-stones measuring about 4 by 3 inches, and $1 \frac{1}{2}$ inches thick; fifty chips and splinters of tlint, but none that can be called a worked implement. With the exception of bones of the Great Auk, the organic remains were those of the existing fauna of the West Coast, among which may be specially mentioned-reddeer, otter, wild-boar, marten, grey and common seal ; remains of one or two cetaceans ; Great Auk, now extinct in Scotland; limpet, pecten, oyster, cockle, crab-all evidently used for edible purposes.

Other Shell-Heaps. - We are informed by Dr. Anderson that two other shell-heaps had been excavated by $\mathrm{Mr}$. Galloway, in Oronsay, in which were found bone and -stone implements, having the same features as those of Caisteal-nan-Gillean. One of these stations was called Croch Sligach, i.e., the shelly mound, and the other Croch Riach, or grey mound. Among the relics from the former were thirty-six of the round-nosed chisels of bone and deer-horn, one hundred and fifty oblong waterworn pebbles with abraded ends, nine rounded pebbles, indented in the middle, supposed to be anvils, and ninety flint chips. It has been noted that the limpets here were exceptionally large, and that some of them were perforated, probably caused by the blow of the implement used to dislodge the mollusc from the rock. The Croch Riach collection contained twenty of the round-nosed chisels, fifty stone implements with the usual abraded and slanting ends, and some forty flint chips.

\section{(7) Shell-Heap on Inchkeith.}

Dr. T. B. Sprague exhibited at a meeting of the Scottish Natural History Society, in 1898, a large quantity of broken bones found in a shell heap or kitchen-midden, on the island of Inchkeith, near Edinburgh, among which were a few of the round-nosed bone chisels similar to those found on the shell-mounds of Oban and Oronsay. Being present at the meeting I took the opportunity of directing the attention of the members to the significance of this fact. 


\section{(8) Sporadic Finds of Harpoons in Britain.}

Victoria Cave, near Settle.-A harpoon (fig. 37), of the same type as the Oban specimen, was found in the Victoria Cave, with regard to which Professor Boyd Dawkins thus writes :

"At the entrance the dark Romano-Celtic or Brit-Welsh stratum lay buried, as we have seen, under an accumulation of angular fragments of stone which had fallen from the cliff. It rested on a similar accumulation, which was no less than six feet thick, and at the bottom of this, at the point where it was on a stiff grey clay, a bone harpoon (fig. 37) was discovered, as well as charcoal ; a bone head, three rude flint flakes, and the broken bones of the brown bear, stag, horse and Celtic shorthorn (Bos longifrons). The harpoon is a little more than 3 inches long, with the head armed with two barbs on each side, and the base presenting a mode of screwing attachment to the handle which has not before been discovered in Britain. Instead of a mere projection to catch the ligatures by which it was bound to the shaft, there is a well-cut barb on either side, pointing in a contrary direction to those which form the head." (Cave-hunting, p. 111.)

Newcastle-upon-Tyne.-On the occasion of a visit to the Antiquarian Museum at Newcastle-upon-Tyne, I saw a bone harpoon (fig. 36 ), labelled as having been picked up on the shore at Whitburn, in 1852. It is of the flat type, has three barbs on one side and two on the other, and contains an oval perforation at the butt-end-in all these respects it agrees with a specimen from Masd'Azil (fig. 11).

Kirkcudbright.-On September 21st, 1900,

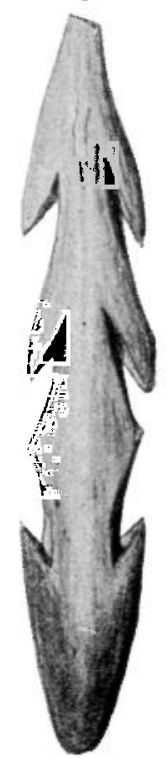

FIG. 37.

Bone harpoon from Victoria

Cave. $\left(\frac{2}{3}\right)$

(From Boyd. Dawkins' CaveHunting.)

I happened to visit a small local museum in the town of Kirkcudbright, and there observed a specimen of a harpoon made of deer-horn (fig. 39, No. 1), which, I was informed, had been found in 1895, in the bed of the river Dee; but, otherwise, it is without a history. It bears a striking resemblance to one of the harpoons from Caisteal-nan-Gillean (fig. 34).

(9) Distribution of Neolithic Harpoons.

Harpoons made of stag-horn have been found in many of the lake-dwellings of Switzerland, especially those of 
the Stone age, a few of which are figured in the various works treating of lacustrine archaeology. Two interesting specimens are here figured (fig. 39, Nos. 2 and 3); the former, found on the lake-dwelling of Concise (Lake Neuchatel), is perforated at the butt, and the other, from Palude Brabbia (in the Varese district),

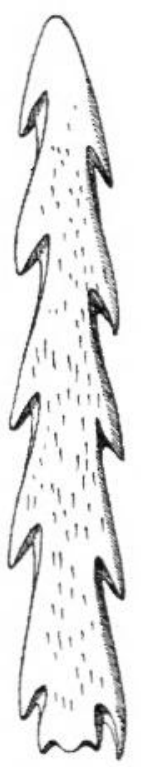

1.

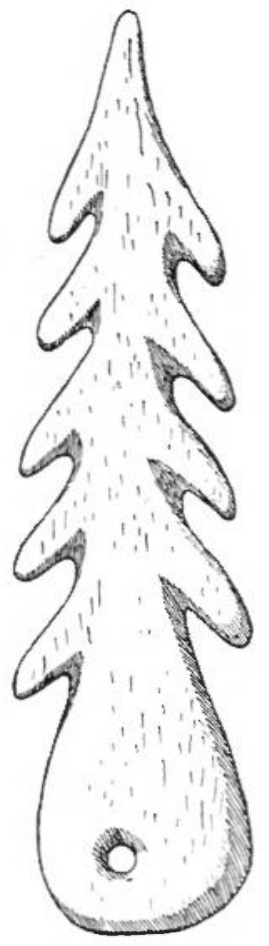

2.

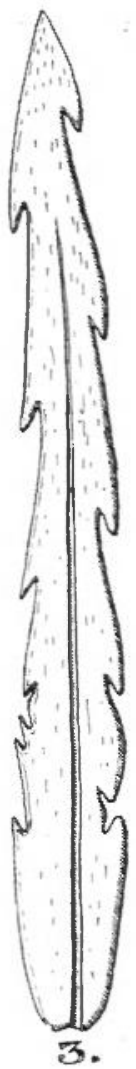

FIG. 39.

Harpoons of stag-horn.-(1) From the bed of the river Dee near Kirkcudbright; (2) from the lake-dwelling of Concise ; (3) from Palude Brabbia (Italy).

(From sketches kindly supplied by W. C. Watson, author of

$$
\text { Portuguese Architecture.) }
$$

exhibits the peculiarity of having the two lower barbs reversed, like the harpoon from the Victoria Cave (fig. 37), already described. Another very large specimen was found in the debris of a lake-dwelling at Steckborn, in the Untersee, which has two notches at the butt-end, 
one on each side, evidently intended for the purpose of giving a catch-hold to the string. Among the other objects from Steckborn lake-dwelling was a hunter's whistle, made of the phalangeal bone of the foot of a deer, precisely similar to those so frequently found on the Palaeolithic stations of France. The harpoon and whistle are figured in The Lake-dwellings of Europe (fig. 28, Nos. 18 and 19). Both these objects must therefore be regarded as transition links between the two civilizations. I am not aware of any argument against the supposition that the Reindeer people had survived on a few stations till the early Neolithic people had founded some of their lacustrine settlements. In the examples of harpoons found on the Swiss lakedwellings the barbs are generally on both sides, and they vary in number from two to twelve, as in fig. 38, which was found at Lattringen.

Dr. Keller gives illustrations of harpoons from Moosserdorf (Lake-dwellings of Switzerland, Plate V, fig. 3), Wauwyl (Ibid., Plate XX, fig. 26), Lattringen (Ibid., Plate XLII, fig. 1), and Concise (Ilid., Plate CIII, figs. 26 and 27). A number is figured in The Lake-dwellings of Europe-one (out of about twenty) found at Cortaillod (fig. 10, No. 8), another from Baldeggersee, being one of four in a small museum at Lucerne (fig. 16, No. 7), a third from the Untersee (already referred to), and a fourth from Maestricht (fig. 94, No. 3). The latter, a fine specimen with twelve barbs, was found

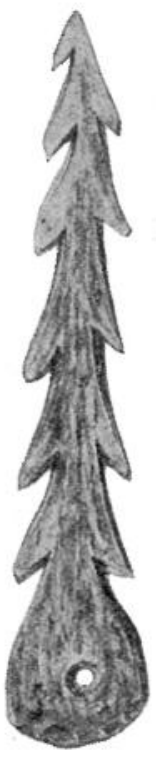

FIG. 39.

Harpoon of deer-horn from Lattriugen. ( $\left.\frac{1}{3}\right)$ on an artificial island constructed of timbers in the valley of the Meuse; and associated with it were a number of other weapons of bone and horn-all of early Neolithic types. One is a perforated piece of staghorn bearing a close resemblance to the axe-hammer head found with the skeleton of a whale in the Carse of Stirling (fig. 31).

Harpoons similar to those from the Oban district, but mostly made of bone, have been largely found on the 
coast kitchen-middens of those primitive camping grounds called Rinnekalns, on the south shore of the Gulf of Finland. At an exhibition of antiquities at the Tenth Archaeological Congress held at Riga, in 1896, a large number of both bilateral and unilateral harpoons were exhibited (Catalogue, Plate I) from the Rinnekalns, and associated with them were various other worked objects of bone, such as needles, awls, pointers, etc., but very few stone implements. Among the food refuse and osseous remains the following fauna were represented: Various kinds of shell-fish, elk (Cervus alces), stag, roe (Bos primigenius), wild-boar, otter, beaver, badger, fox, $\operatorname{dog}$ (Canis familiaris).

Two fish-spears of a very remarkable character are figured in The Lake-dwellings of Europe (fig. 30, Nos. 3 and 5). They were found on the station of Bodmann, in the Ueberlingersee. Their peculiarity is that one has two prongs, and the other four, formed by cutting away the interior of a thick portion of stag-horn, as well as portions of the circumference, so as to leave the prongs in the solid, each prong having only one barb. Harpoons of bone and horn, with only one prong and one barb, have been occasionally met with; but such instruments were not common until metals were introduced and utilized in the manufacture of all kinds of cutting implements. Examples made of bronze were among the relics fished up at Peschiera in Lake Garda (Lake-dwellings of Europe, fig. 64, Nos. 20, 21 and 30).

\section{(10) Rock-shelter of Schweizersbild.}

Hitherto the evidential materials under review consisted of a few relics of primitive life, chiefly harpoons, with the object of showing that they were connecting links between the Palaeolithic and Neolithic ages. We now come to certain post-glacial deposits on an inhabited site, which have yielded to their excavator, Dr. Nüesch, not only relics of the hunters who frequented it, but remains of the animals on which they feasted, in sufficient abundance to enable experts to make out a complete list of the ordinary fauna of the period. It has been shown that, during the occupancy of this rock-shelter by man, 
there had been a gradual transition from an arctic to a temperate climate. The contents of these deposits indicate that the locality had been a constant rendezvous for bands of roving hunters from the Palaeolithic period down to the Bronze age. As I have on a previous occasion (address delivered at Lancaster, July 19th, 1898), directed the attention of the members of this Association. to the remarkable discoveries at Schweizersbild, it will be unnecessary now to do more than to explain briefly the nature of the light which they throw on the transition. period.

Dr. Nüesch has expressed the opinion, founded on the relative thickness of the deposits and the character of the fauna represented in them, that the antiquity of its earliest human relics cannot be less than 20,000 years. Now, since the art-remains found in this station, as well as in the adjacent cave of Kesslerloch, are precisely similar to those of the analogous stations in France, we can accept the above estimate as equally applicable to. the latter. The nature of the evidence on which Dr. Nüesch based his opinion is briefly as follows :

According to Professor Nehring, who has made a special study of the animals now inhabiting the arcticand sub-arctic regions, those characteristic of the former are band-lemming, obi-lemming, arctic fox, mountain hare, reindeer, and musk-ox. With these are frequently associated a number of animals of migratory habits, such as northern vole, water-rat, glutton, ermine, little weasel, wolf, fox, and bear. Now, the extraordinary fact was. brought out that of these fourteen species only the obilemming and the musk-ox were unrepresented in thelowest relic-bed of the Schweizersbild. The latter was, however, found in the debris of the Kesslerloch cave in the vicinity. It appears that the band-lemming (Myodes torquatus) and the arctic fox are the most persistent animals of the arctic fauna, so that the presence of the bones of these two animals in the debris of this rockshelter was alone sufficient to prove that the climate of the period was of an arctic character. In the upper portion of this deposit relics of new animals, indicating $\mathbf{a}$ change to a sub-arctic climate, began to appear, and had their greatest development in the next succeeding layer. 
The result of careful analysis of the contents of the other deposits showed that this arctic fauna became ultimately displaced by the true forest fauna of the Neolithic period. Among the new comers were the badger, wild-cat, hare, Urus, Bos-longifrons, goat and sheep; while of those represented in the Palaeolithic deposit a large number was absent. Thus both the arctic and sub-arctic fauna had given way to a forest fauna, and, synchronous with these changes, both the Palaeolithic hunters and reindeer appear to have vanished from the district.

Among the few art specimens found in the debris at the Schweizersbild is a stone tablet, having rude outlines of a wild ass and of a reindeer incised upon it. The whole collection - among which were 14,000 worked flints, 180 fragments of bone needles, 41 whistles, 42 pierced ornaments made of shells, and teeth of the arctic fox, glutton, etc., may be paralleled with the latest phase of Palaeolithic civilization of the Dordogne Caves.

The chronological deductions founded on the investigations at the Schweizersbild are, from their very nature, more or less hypothetical. But, after all allowances for possible errors are made, I can see no objection to Dr. Nüesch's lowest estimate of the date of man's first appearance in Northern Switzerland, viz., 20,000 years ago.

From these facts it will be seen that in this part of Switzerland there had been no discontinuity in human existence since the inhabitants hunted the reindeer and other arctic animals till the present day. It would appear as if they had gradually adapted themselves to the changes in the environment, passing insensibly from a climate of sub-arctic severity, with its special flora and fauna, to that of modern times. Harpoons of reindeer or red-deer horn are not conspicuous objects among the relics, but this may arise from provincialism, as separate districts often develop peculiar methods of living and hunting. The relics from other transition stations are found to be equally variable in their facies; but this only shows that in the struggle for existence the various communities were shaping their own destinies. 


\section{(11) Hut-dwellings at Campigny.}

Among the archaeologists who did not agree with the theory that the old indigenous inhabitants of Central Europe, along with their flint and bone industries, had come to an end with the disappearance of the reindeer, was Dr. Salmon, who maintained that traces of a gradual transformation were to be found on many of the earlier Neolithic sites. In 1898 an important article, entitled Le Campignien, under the joint names of Philippe Salmon, D'Ault du Mesnil and Capitan, was published in the Revue de l'Ecole d'Anthropologie (p. 365 et seq.), the object of which was to show, that certain hut-dwellings excavated at Campigny belonged to the earliest phase of the Neolithic period. The worked flints were numerous and varied, including several Palaeolithic types and at least one special implement, called le tranchet, which the authors regarded as characteristic of the period. Analogous remains were stated to have been found in a great many other localities, but, as Campigny was considered the most typical station, I have selected it as most suitable for giving a brief description of this class of evidence against the hiatus theory.

The hillock of Campigny is situated about two kilometers to the north of the picturesque village of Blangysur-Bresle (Seine-Inferieure), and remarkably well placed for natural defence. The sites of the dwelling-huts were circular pits, excavated in Quaternary gravels, and measuring a few yards in diameter and about 4 feet in depth, which in the course of time became filled up with debris; and so their contents were preserved from decay. The industrial relics collected consist of hearths, remains of stone industry, and fragments of a coarse pottery. Some fragments of pottery are rudely ornamented with cross lines on quadrilateral spaces while others indicate perforated handles, or ears. Among the stone relics are small axes, precisely similar to those found in the Danish Kjokkenmoddings, knife flakes, scrapers, etc., but no polished objects. It would thus appear as if the invention of pottery preceded that of the art of giving a sharp edge, by polishing, to a stone implement-a deduction to which the authors direct special attention. There 
are also some large flat stones showing marks of rubbing, as well as the usual hand-rubbers, supposed to have been used for grinding grain and seeds. The number of separate hearths indicates communal life and a social organization of some kind. As to the kind of huts which these people constructed there is no evidence to show. Chronologically the authors recognise this settlement as on the same horizon as the rock-shelter of Mas-d'Azil, and to the phase of Neolithic civilization it represents they have given the name Campignien.

From the relics found in the debris of the huts at Campigny, and illustrated in the interesting paper above referred to, I have copied a few specimens of the pottery (Plate I, Nos. 1-4) and a few flint implements showing three specimens of the tranchet (Nos. 7, 8 and 9), a pick (No. 10), a double scraper (Magdalenien type) (No. 6), and a saw (No. 5), which will give some idea of the culture of the people during the so-called Campigny epoch. But archaeological discoveries in several other localities are probably equally specialized and as worthy of being regarded as typical of some phase of the transition period, and if all such differences are to be adopted as generic characters there will be no end to the making of transitional epochs. The truth is, that every separate locality practised its own peculiar methods in adjusting its wants and necessities, not only to the progressive changes in the physical environment, but also to the expanding world of intellectuality. Mechanical improvements appeared now and then as sporadical inventions, but, as soon as they were recognised to be a permanent benefit to the community, they were utilized over larger areas and became recognized objects of commerce.

A propos to the tranchet, which, as we have seen, is the characteristic implement in the Campigny epoch, M. Georges Romain describes in the Revue de l'Ecole d'Anthropologie for 1896 what he regards as an atlier de Tranchets, at Coudraie, near Montivilliers(SeineInfërieure). This factory was situated on the declivity of rising ground and occupied an area of 150 mètres by 100 mètres. In the course of a few visits M. Romain and a friend gathered some 90 ordinary sized tranchets, and 4 small ones (which might be regarded as arrow points ("a tranchant trans- 


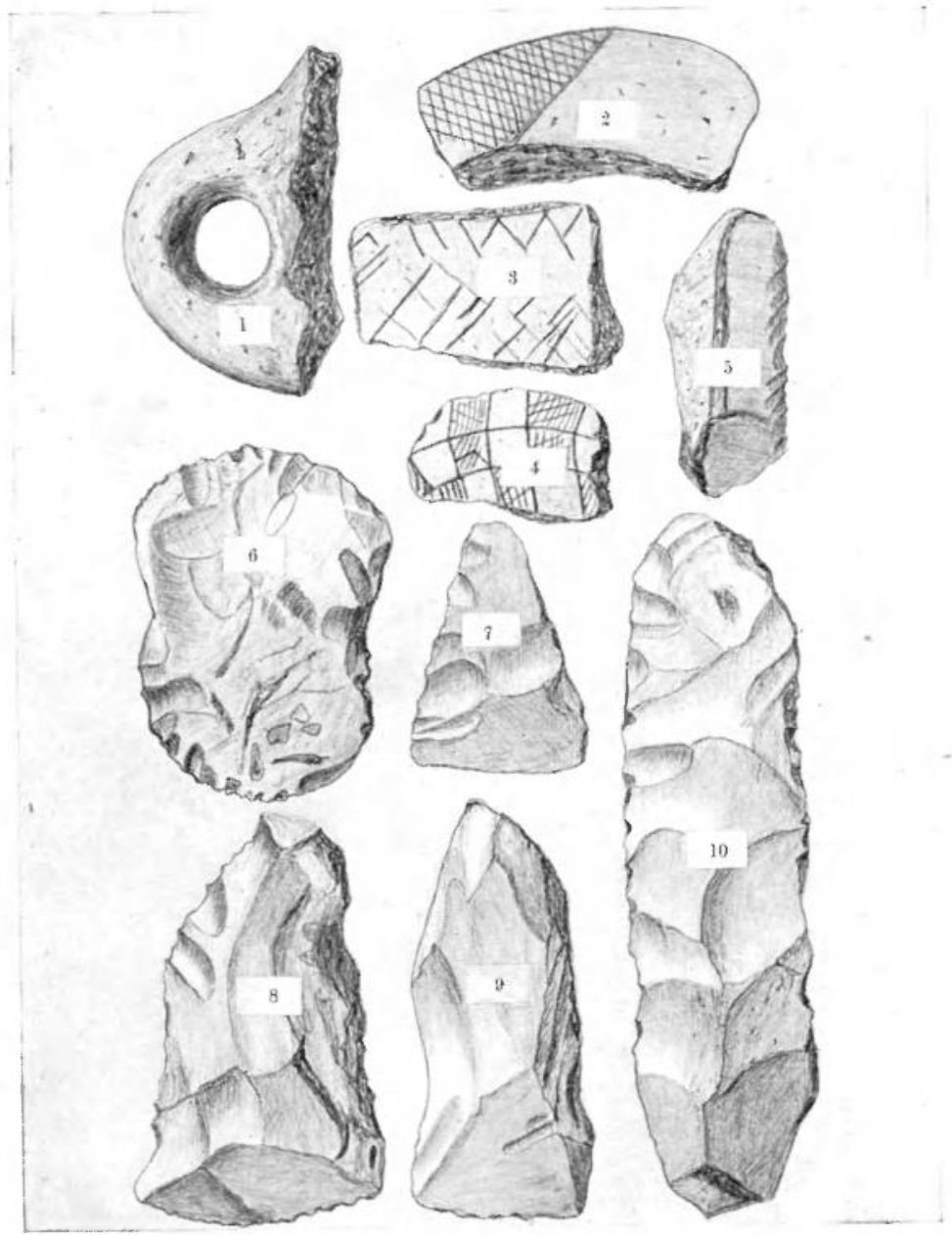

SPECIMENS OF POTTRRY ( 1 TO 4) AND FLINT IMPLEMENTS (5 to 10) FBOM THE

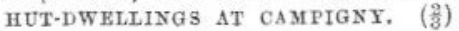


versal "), together with a number of scrapers, borers, flakes, etc. Two of the tranchets are figured on page 149 of the above-named volume, and they appear to be exceptionally well made. They measure on an average 42 millimetres by 29 millimetres at the cutting edge.

The question whether the tranchet is a characteristic implement of the transition period is still the cause of much discussion among Continental anthropologists. That it has been found on inhabited sites of the Neolithic age is universally admitted, but this is no proof that it had not been a special tool before the art of polishing stone implements was invented. In Scandinavia the tranchet, which is a characteristic relic of the Kjokkenmöddings, disappeared on the advent of the polished stone axe; but in some other countries it appeared to have survived longer. (For an important discussion on Campignien and Campigny, see Bull. de la Societe d'Anthropologie de Paris, January $1^{4}$ th, 1899 .)

\section{(12) Tardenoisien Flint Industry.}

The existence in various parts of the world of small flint instruments and tools affecting geometrical forms, such as triangle, trapeze, rhomboid, segment of a circle, etc., has been known to archaeologists for some years. This particular kind of flint industry is now regarded as a special link-another epoch-between the Palaeolithic and Neolithic civilizations, under the name of Tardenoisien, after Fere-en-Iardenois (Aisne), in the environs of which these small worked flints have been abundantly found. They have also been frequently met with both on the later Palaeolithic stations and on Neolithic sites. In England they have been found by Mr. Abbott in the Hastings' Kitchen Middens (Journal of the Anthropological Institute of Great Britain and Ireland, vol. xxv, p. 122), and by Dr. Colley March on Neolithic floors in East Lancashire. Under peat, Dr. March came upon the site and debris of a flint factory, with regard to which he thus writes:

"The most remarkable and characteristic part of his workmanship ('Neolithic tool-wright') lay in the production of a number of minute implements, used 
probably for boring eyes in bone needles, for engraving patterns on shafts and handles, and perhaps for tattooing.

"Tools of fint, so diminutive as these, some of which are only a quarter of an inch long, have, I believe, been found in no other part of the world. But they made other implements in great variety, knives, scrapers, both hafted scrapers and thumbstones, some of the latter being very small, arrow-tips, spear-tips, and, as I think, fishthrottles. Not one of the implements is polished, and there is no trace of the local manufacture of barbed arrow-heads. Neither is there any sign of pottery, or of a knowledge of spinning. We may believe, too, that these early Neolithic men were ignorant of agriculture, that they lived by the chase, and that they clothed themselves in skins as a protection against a severe climate." (The Neolithic Men of Lancashire, etc., p. 12.)

Baron A. de Loe announced at the Monaco Meeting of the International Congress of Anthropology and Prehistoric Archaeology for 1907 (Compte Rendu, p. 423) the finding of characteristic Tardenoisien flints in the Grotte de Remouchamps, sur l'Amblene (Holland), associated with remains of the reindeer.

\section{(13) A Floating Lacustrine Station.}

For more than half a century the Kjokkenmöddings of Denmark have been known as containing the oldest traces of man in Scandinavian lands-among which, singular enough, the veritable tranchet forms a conspicuous relic. Many of the Scandinavian archaeologists have long regarded these remains as belonging to an age which preceded the true Neolithic, or polished Stone age. At the meeting of the Congres Prehistorique de France, held at Perigueux, in 1906, M. Georges F. L. Sarauw read a paper, entitled "Sur les trouvailles faites dans le Nord de l'Europe datant de la. periode dite de l'hiatus."

From this communication it appears that in the island of Seeland a remarkable discovery has been made in a peat-bog (formerly the bed of a lake), called 
Maglemose, in the form of a lacustrine station, distant several hundred yards from the old shore of the lake, on which were found a large assortment of worked flints, and implements of bone and horn, together with the osseous remains of animals and other food refuse. The most puzzling feature of the discovery was the entire absence of piles for supporting platforms on which the dwelling huts are usually placed-a peculiarity which could not be due to the decay of the piles, as there was a large quantity of wood well preserved in the moss. The conclusion arrived at was that it was a huge raft, or floating island, and probably the precursor of the famous pile-structures of the Stone and Bronze ages of Central Europe. Among the flint relics are scrapers, picks, tranchets, borers, flakes, nuclei, etc. But of greater interest are the objects made of bone and horn, such as socketed axes, made of the bones of the Urus, and of staghorn daggers, needles, ornaments, fish-hooks, polishers, and especially sagaies, and harpoons made of bone. The latter assume different forms, but the barbs are unilateral -except in a special form which consisted of a smooth stem with a slit on each side into which thin flakes of flint were inserted. Among the thousands of worked objects of flint collected on this station there was none showing any trace of polish, nor was there a single fragment of pottery found. The archaeological horizon of this strange settlement agreed with that of Campigny in its tranchets, with that of Fere-en-Tardenois in its diminutive flint implements, and with that of Mas-d'Azil in its harpoons. On geological grounds, as well as on the evidence of its flora and fauna, it has been placed earlier than the Kjokkenmoddings. M. Sarauw, after noticing the distribution of other early remains in the north of Europe, concludes thus: "Ainsi, pour le Nord de l'Europe comme pour l'Ouest, la lacune, l'ancien hiatus, vient d'etre comble."

\section{(14) Kjokkenmoddings in Portugal.}

Excluding the caves and rock-shelters frequented by Palaeolithic man, only a few inhabited sites, associated with shell-heaps and other food refuse, can with certainty 
be assigned to the transition period, although, within recent years, their number has considerably increased. The Kjokkenmoddings of Denmark, to which reference has already been made in this article as belonging to this period, are too well known to be described in detail here. Among the less known of the early haunts of man, one of the most interesting was discovered in 1863, in the valley of the Tagus, near the villages of Salvaterra and Mugem. The shell-heaps are grouped on the left bank of the river at from 25 to 30 metres above sea-level, but distant some 30 or 40 miles from the maritime shores of the present embouchure of the Tagus. They are scattered over an area measuring 20 kilometres in length by 5 in breadth. One of these monticules, called Cabeço da Arruda, had an elliptical shape, and measured about 100 metres in length, 60 metres in breadth, and 7 metres in thickness. A short description of their nature and contents was given by M. C. Ribeiro in 1880, at the meeting of the International Congress of Anthropology and Prehistoric Archaeology then held at Lisbon. The shells are of marine origin, and it is supposed that when the shells were gathered and used as food the sea extended up the valley as far as the shell-mounds. The industrial remains disclosed by excavations are of a very rude character, consisting of primitive implements made of flint, quartzite, bone and horn. Among the flints illustrated are a few knife flakes, and some small cutting implements of rhomboidal forms, "a tranchant transversal," reminding one of the Tardenoisien industry. Also, some large flat stones, used apparently for grinding purposes, together with the smaller hand rubbers. Horn and bone were used as chisels, pointers, spatulae, etc. No polished axes, nor pottery, nor any indications of domestic animals, not even the dog (which the people of the Danish Kjokkenmöddings had domesticated), have been found in any of these shell-mounds. The animal remains belonged to the following genera : Bos, Cervus, Ovis, Equus, Sus, Canis, Felis, Meles, Viverra, Lepus; and the shells were mostly Lutraria compressa, and in a minor degree there were also Tapes, Cardium, Ostrea, Buccinum, Nucula, Pecten and Solen.

Perhaps the most interesting feature of the investiga- 
tions was the discovery of upwards of a hundred interments, at various depths in the shell-mounds; but it does not appear that any grave-goods had been associated with them. The osseous remains were much decayed, and the skulls distorted, probably by the pressure of the debris. Enough, however, remained to show that they represented two races-one dolichocephalic and the other brachycephalic. Some of the crania were recognised by M. de Quatrefages, and other anthropologists present at the Congress, as belonging to the types of Cromagnon and Furfooz. Of the latter, only two specimens were in the series, all the others being dolichocephalic, with a cephalic index of $71 \cdot 11$ to $75 \cdot 56$. One of the brachycephalic skulls had a cephalic index of 86.90 . A reasonable inference from these archaeological data is that the builders of the shell-mounds in the valley of the Tagus were a mixed community, the great majority of which belonged to the old Palaeolithic people of Europe, while the minority formed part of the earliest immigrants of the Neolithic races into Europe.

\section{(15) General Conclusion.}

From these recorded facts and observations we see that, at the dawn of Neolithic civilization, there extended over Western Europe a primitive population living on shellfish, the produce of the chase, seeds, fruits, roots, etc., varying according to the natural resources of the environment. The finding of the foundations of huts in selected localities shows that they lived a communal life; but their domestic economy was of a low order, having only roughlyformed implements of stone, bone and horn. They had no ornaments, no pottery and no domestic animals, with the possible exception of the dog. But even at this early stage there were two well-defined races apparently living in harmony with each other-one dolichocephalic and the other brachycephalic. The former, who were greatly in excess of the latter in the western regions of Europe, appear to have been indigenous to the country, being probably the direct descendants of the Palaeolithic people who, so far as can be judged from the most trustworthy anthropological researches, were all dolichocephalic. The latter, 
or brachycephals, on their first appearance in Europe were not more civilised than the former, but a constant stream of immigrants was kept up, and ultimately introduced improved methods in the cultivation of grain, and in the rearing of domestic animals. The French troglodytes lived as isolated hunters till the wild animals - mammoth, reindeer, horses, etc.-which formed the staple of their food, died out in the locality, owing probably to a change of climate. Contemporary with them, but outside the areas of their hunting grounds, these other communities were developing new resources for the supply of the necessaries of life among the increasing products of a more ameliorated climate. It is quite possible that certain districts of Europe which were formerly inhabited by Palaeolithic hunters ceased, for some reason or other, to be places of resort to man. Britain in Quaternary times was joined to the Continent, and it is probable that its later Palaeolithic inhabitants, such as those of Kent's Cavern, could join hands with French troglodytes on the intervening common hunting grounds now forming the bed of the English Channel. When Palaeolithic civilization began to be curtailed in virtue of cosmic changes in the environment, and new methods of living were forthcoming, it is possible that the British fringe of the Palaeolithic population would shrink back to Europe, and thus, for a time, leave a gap in the continuity of human life in Britain. On this point there is no evidence; but it is only a side issue to the European Hiatus-problem.

The power of adaptation to changed circumstances may almost be regarded as a monopoly of the human race, and no doubt it took effect in a variety of ways in different geographical areas. We could hardly expect to find in every locality precisely the same facies in the progressive arts and industries. Something must be due to the genius loci, and the inventive faculty of individuals. Hence the archaeological hiatus, like the geological cataclysms of the days of yore, must be relegated to the lumber room of dead theories. 